NASA/TM-2000-209891, Vol. 170

Technical Report Series on the Boreal Ecosystem-Atmosphere Study (BOREAS)

Forrest G. Hall and Andrea Papagno, Editors

Volume 170

BOREAS TE-12 Incoming PAR

Through the Forest Canopy Data

Elizabeth A. Walter-Shea and Mark A. Mesarch

University of Nebraska-Lincoln

National Aeronautics and

Space Administration

Goddard Space Flight Center

Greenbelt, Maryland 20771 
Available from:

NASA Center for AeroSpace Information 7121 Standard Drive

Hanover, MD 21076-1320

Price Code: A17
National Technical Information Service 5285 Port Royal Road Springfield, VA 22161

Price Code: A 10 


\title{
BOREAS TE-12 Incoming PAR Through the Forest Canopy Data
}

\author{
Elizabeth A. Walter-Shea, Mark A. Mesarch
}

\section{Summary}

The BOREAS TE-12 team collected PAR data sets in support of its efforts to characterize and interpret information on shoot geometry, leaf optical properties, leaf water potential, and leaf gas exchange. The data were collected at the SSA-OBS site from 04-Jul-1996 to 25-Jul-1996. The data are stored in tabular ASCII files.

\section{Table of Contents}

1) Data Set Overview

2) Investigator(s)

3) Theory of Measurements

4) Equipment

5) Data Acquisition Methods

6) Observations

7) Data Description

8) Data Organization

9) Data Manipulations

10) Errors

11) Notes

12) Application of the Data Set

13) Future Modifications and Plans

14) Software

15) Data Access

16) Output Products and Availability

17) References

18) Glossary of Terms

19) List of Acronyms

20) Document Information

\section{Data Set Overview}

\subsection{Data Set Identification}

BOREAS TE-12 Incoming PAR Through the Forest Canopy Data

\subsection{Data Set Introduction}

The Terrestrial Ecology (TE)-12 team took measurements of incoming photosynthetically active radiation (PAR) as part of the BOReal Ecosystem-Atmosphere Study (BOREAS) at the Old Black Spruce (OBS) site in the Southern Study Area (SSA) from 04-Jul-1996 to 25-Jul-1996. PAR, in units of micro Einsteins per meter squared per second, from 0.4 to 0.7 microns, was measured in an array below the tree canopy, but above the understory. Ten LI-COR quantum sensors measured PAR, and minute averages are reported.

\subsection{Objectives/Purpose}

The objective of this research was to characterize the duration and magnitude of sun flecks under a boreal forest canopy. 


\subsection{Summary of Parameters}

Minute averages of PAR, in units of micro Einstein per meter squared per minute.

\subsection{Discussion}

TE-12 took measurements of incoming PAR at SSA-OBS from 04-Jul-1996 to 25-Jul-1996. PAR, in units of micro Einsteins per meter squared per second, from 0.4 to 0.7 microns, was measured in an array below the tree canopy, but above the understory. Ten LI-COR quantum sensors measured PAR, and minute averages are reported.

\subsection{Related Data Sets}

TE-12 Shoot Geometry Data

TE-12 Leaf Gas Exchange Data

\section{Investigator(s)}

\subsection{Investigator(s) Name and Title}

Elizabeth A. Walter-Shea, Assoc. Professor

\subsection{Title of Investigation}

Radiation and Gas Exchange of Canopy Elements in a Boreal Forest

\subsection{Contact Information}

\section{Contact 1:}

Mark A. Mesarch

University of Nebraska

14 LW Chase Hall

Lincoln, NE 68583-0728

(402) 472-5904

(402) 472-0284

(402) 472-6614 (fax)

mmesarch1@unl.edu

\section{Contact 2:}

Elizabeth A. Walter-Shea

University of Nebraska

246 LW Chase Hall

Lincoln, NE 68583-0728

(402) 472-1553

(402) 472-6614 (fax)

ewalter-shea1@unl.edu

\section{Contact 3:}

Andrea Papagno

Raytheon ITSS

NASA GSFC

Code 923

Greenbelt, MD 20771

(301) 286-3134

(301) 286-0239 (fax)

Andrea.Papagno@gsfc.nasa.gov 


\section{Theory of Measurements}

Fluxes need to be measured at understory levels to relate to environmental and state variables and explain the stand scale fluxes. At the understory level, upper canopy elements shade the understory partially, creating sun flecks. These sun flecks fluctuate over time, both spatially and in intensity. An array of hemisphere sensors was placed above the understory to measure a represented area of transmitted PAR. The time frame of the measurements, 1 -minute averages, provided a time scale representative of a plant's photosynthetic processes' reaction time.

\section{Equipment}

\subsection{Sensor/Instrument Description}

A LI-COR Quantum Sensor (LI-190SA) was used to detect sun flecks. A silicon photo diode with an enhanced response in the visible wavelengths was used to measure PAR, from 0.4 to 0.7 microns. A visible bandpass interference filter, in combination with color glass filters, was mounted in a cosine corrected head. Error calculations indicated that under sun-and-sky radiation, and under various natural or artificial light sources, the relative measurement errors are less than $5.0 \%$. Therefore, this sensor can be used within or inverted over canopies and in greenhouses, controlled growth chambers, and confined laboratory conditions. Generally, this instrument measures hemispherical incoming radiation; however, when placed within a canopy, the instrument acts as a point source detector.

The quantum sensors were placed in an array surrounding a central point at varying distances from this central point. The table below describes the directions and distances from the central point for sensor.

\begin{tabular}{|c|c|c|}
\hline Sensor serial number & Direction & Distance (m) \\
\hline Q15566 & North & 15 \\
\hline Q9020 & Northeast & 16 \\
\hline Q15565 & East & 10 \\
\hline Q2738 & East-Southeast & 2.5 \\
\hline Q9123 & Southeast & 12 \\
\hline Q9022 & South & 12 \\
\hline Q7433 & South-Southwest & 1.7 \\
\hline Q7434 & Southwest & 5 \\
\hline Q10890 & West & 12 \\
\hline Q89085 & Northwest & 4.5 \\
\hline
\end{tabular}

\subsubsection{Collection Environment}

Measurements were made onsite at the SSA-OBS site.

\subsubsection{Source/Platform}

Each LI-COR quantum sensor was attached to a LI-COR 2003S Mounting and Leveling Fixture. These fixtures are made of anodized aluminum with stainless steel leveling screws and a weatherproof spirit level. The fixture was attached to a wood block that was attached to the top of a pole, $0.6 \mathrm{~m}$ above the sphagnum surface. Once the wood block was attached to the pole, the leveling screws on the fixture were used to level the fixture holding the quantum sensor.

\subsubsection{Source/Platform Mission Objectives \\ None given.}

\subsubsection{Key Variables \\ Incoming PAR under a tree canopy.}




\subsubsection{Principles of Operation}

The LI-COR quantum sensor uses a silicon diode to convert sunlight to electrical energy (voltage).

\subsubsection{Sensor/Instrument Measurement Geometry}

The quantum sensors were placed in an array surrounding a central point at varying distances from this central point. The table below describes the directions and distances from the central point for sensor.

\begin{tabular}{cllc} 
Sensor serial number & & Direction & Distance (m) \\
\cline { 1 - 1 } Q15566 & & North & 15 \\
Q9020 & Northeast & 16 \\
Q15565 & & East & 10 \\
Q2738 & East-Southeast & 2.5 \\
Q9123 & Southeast & 12 \\
Q9022 & South & 12 \\
Q7433 & South-Southwest & 1.7 \\
Q7434 & Southwest & 5 \\
Q10890 & West & 12 \\
Q89085 & Northwest & 4.5
\end{tabular}

Each LI-COR quantum sensor was attached to a LI-COR 2003S Mounting and Leveling Fixture. These fixtures are made of anodized aluminum with stainless steel leveling screws and a weatherproof spirit level. The fixture was attached to a wood block that was attached to the top of a pole $0.6 \mathrm{~m}$ above the sphagnum surface. Once the wood block was attached to the pole, the leveling screws on the fixture were used to level the fixture holding the quantum sensor.

\subsubsection{Manufacturer of Sensor/Instrument \\ LI-COR, Inc. \\ Box 4425 \\ Lincoln, NE 68504 \\ (402) 467-3576}

\subsection{Calibration}

\subsubsection{Specifications}

None given.

\subsubsection{Tolerance}

None given.

\subsubsection{Frequency of Calibration}

LI-COR quantum sensors were calibrated at the manufacturer in May 1996. 


\subsubsection{Other Calibration Information}

Calibration coefficients for the sensors were in units of micro Einsteins per meter squared per second per millivolt.

\begin{tabular}{|c|c|c|}
\hline Sensor Number & Serial Number & Coefficient \\
\hline 1 & Q9020 & -253.54 \\
\hline 2 & Q9022 & -282.05 \\
\hline 3 & Q7434 & -252.00 \\
\hline 4 & Q9123 & -308.31 \\
\hline 5 & Q15566 & -311.21 \\
\hline 6 & Q15565 & -245.64 \\
\hline 7 & Q89085 & -285.45 \\
\hline 8 & Q10890 & -286.44 \\
\hline 9 & Q7433 & -200.00 \\
\hline 10 & Q2734 & -194.55 \\
\hline
\end{tabular}

\section{Data Acquisition Methods}

The quantum sensors were placed in an array surrounding a central point at varying distances from this central point. The sensors were placed in the array to cover an area of approximately $600 \mathrm{~m}^{2}$, which was representative of an area of understory under the canopy. The table below describes the directions and distances from the central point for sensor.

\begin{tabular}{cllc} 
Sensor serial number & & Direction & Distance (m) \\
\cline { 1 - 1 } Q15566 & & North & 15 \\
Q9020 & Northeast & 16 \\
Q15565 & & East & 10 \\
Q2738 & & East-Southeast & 2.5 \\
Q9123 & Southeast & 12 \\
Q9022 & South & 12 \\
Q7433 & South-Southwest & 1.7 \\
Q7434 & Southwest & 5 \\
Q10890 & West & 12 \\
Q89085 & Northwest & 4.5
\end{tabular}

Each LI-COR quantum sensor was attached to a LI-COR 2003S Mounting and Leveling Fixture. These fixtures are made of anodized aluminum with stainless steel leveling screws and a weatherproof spirit level. The fixture was attached to a wood block that was attached to the top of a pole, $0.6 \mathrm{~m}$ above the sphagnum surface. Once the wood block was attached to the pole the leveling screws on the fixture were used to level the fixture holding the quantum sensor. Data were measured every 5 seconds and reported as 1 -minute averages.

\section{Observations}

\subsection{Data Notes}

None given.

\subsection{Field Notes \\ None given.}




\section{Data Description}

\subsection{Spatial Characteristics}

\subsubsection{Spatial Coverage}

The SSA measurement site and its associated North American Datum of 1983 (NAD83) coordinates are:

- SSA-OBS, site id G8I4T, Lat/Long: 53.98717_N, 105.11779_W, Universal Transverse Mercator (UTM) Zone 13, N: 5,982,100.5, E: 492,276.5.

\subsubsection{Spatial Coverage Map}

Not applicable.

\subsubsection{Spatial Resolution}

The maximum distance between any two quantum sensors was 27 meters. The entire array covered approximately $600 \mathrm{~m}^{2}$.

\subsubsection{Projection}

Not applicable.

\subsubsection{Grid Description}

Not applicable.

\subsection{Temporal Characteristics}

\subsubsection{Temporal Coverage}

Data were collected at the OBS-SSA site From 04-Jul-1996 to 25-Jul-1996.

\subsubsection{Temporal Coverage Map}

Not available.

\subsubsection{Temporal Resolution}

Data were collected on most days from sunrise to sunset (approximately 4 a.m. to 10 p.m. local time). Measurements were made every 5 seconds and reported as 1-minute averages.

\subsection{Data Characteristics}

\subsubsection{Parameter/Variable}

The parameters contained in the data files on the CD-ROM are:

COIUmn Name
SITE_NAME
SUB_SITE
DATE_OBS
TIME_OBS
MEAN_DIR_DOWN_PEED_SNSR1
MEAN_DIR_DOWN_PPED_SNSR2
MEAN_DIR_DOWN_PPED_SNSR3
MEAN_DIR_DOWN_PPED_SNSR4
MEAN_DIR_DOWN_PPFD_SNSR5
MEAN_DIR_DOWN_PPFD_SNSR6
MEAN_DIR_DOWN_PPED_SNSR7
MEAN_DIR_DOWN_PPED_SNSR8




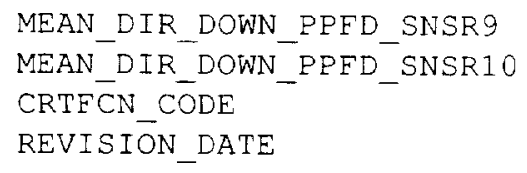

\subsubsection{Variable Description/Definition}

The descriptions of the parameters contained in the data files on the CD-ROM are:

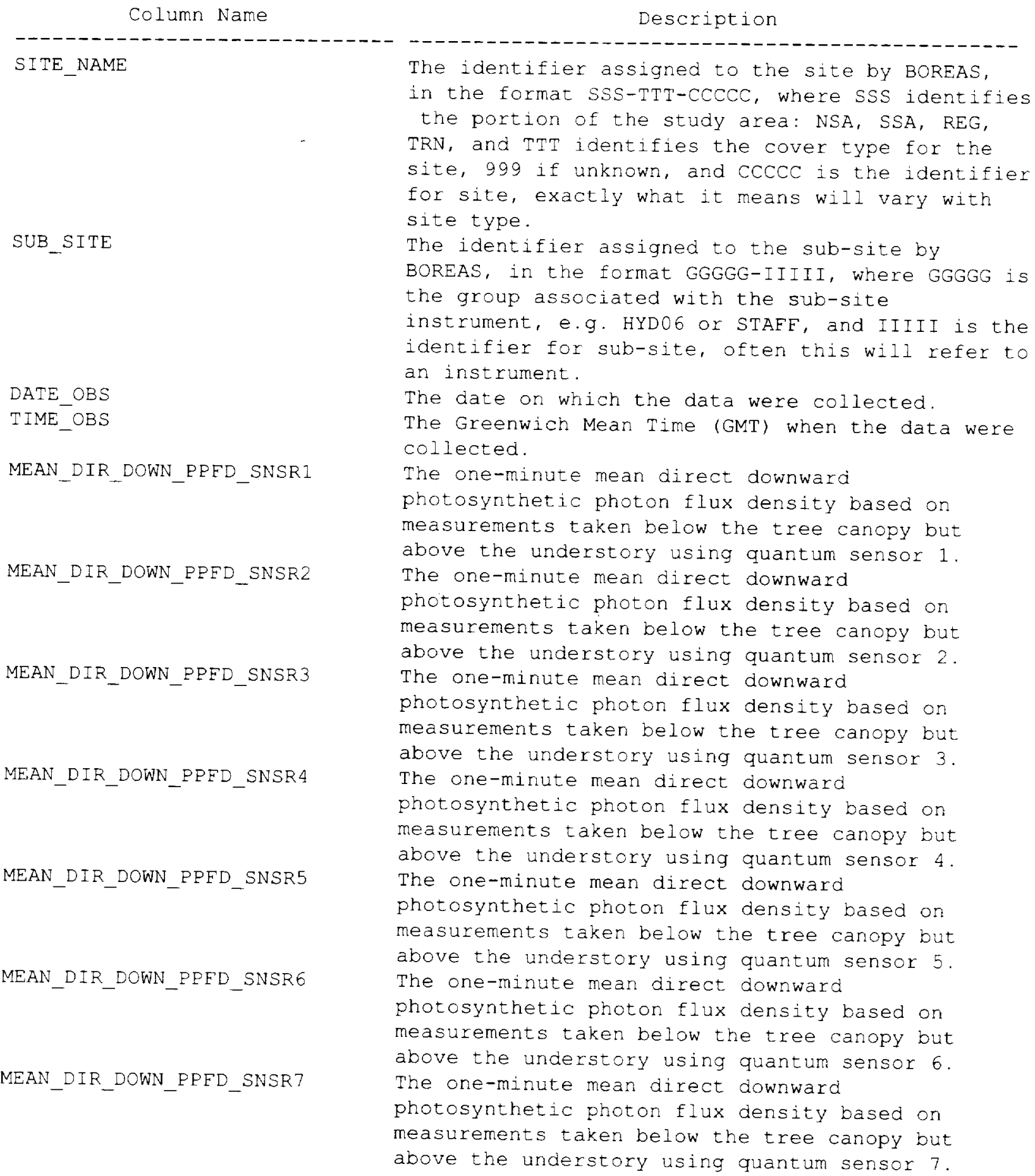

Page 7 


\section{Data Manipulations}

\subsection{Formulae}

None.

9.1.1 Derivation Techniques and Algorithms

Not applicable.

\subsection{Data Processing Sequence}

None given.

\subsubsection{Processing Steps}

None given.

\subsubsection{Processing Changes}

None given.

\subsection{Calculations}

\subsubsection{Special Corrections/Adjustments}

None given.

\subsubsection{Calculated Variables}

None given.

\subsection{Graphs and Plots}

None given.

\section{Errors}

\subsection{Sources of Error}

The manufacturer estimates that the LI-COR quantum sensor will measure within $+/-5.0$ percent relative error of the true incoming PAR.

\subsection{Quality Assessment}

\subsubsection{Data Validation by Source} None given.

\subsubsection{Confidence Level/Accuracy Judgment} None given.

\subsubsection{Measurement Error for Parameters}

None given.

\subsubsection{Additional Quality Assessments}

None given.

\subsubsection{Data Verification by Data Center}

Data were examined for general consistency and clarity. 


\section{Notes}

\subsection{Limitations of the Data}

None given.

\subsection{Known Problems with the Data}

None given.

\subsection{Usage Guidance}

None given.

11.4 Other Relevant Information

None given.

\section{Application of the Data Set}

This data set can be used to study the incoming PAR of the boreal forest.

\section{Future Modifications and Plans}

None given.

\section{Software}

\subsection{Software Description}

None given.

\subsection{Software Access}

None given.

\section{Data Access}

The incoming PAR data are available from the Earth Observing System Data and Information System (EOSDIS) Oak Ridge National Laboratory (ORNL) Distributed Active Archive Center (DAAC).

\subsection{Contact Information}

For BOREAS data and documentation please contact:

ORNL DAAC User Services

Oak Ridge National Laboratory

P.O. Box 2008 MS-6407

Oak Ridge, TN 37831-6407

Phone: (423) 241-3952

Fax: (423) 574-4665

E-mail: ornldaac@ornl.gov or ornl@eos.nasa.gov 


\subsection{Data Center Identification}

Earth Observing System Data and Information System (EOSDIS) Oak Ridge National Laboratory (ORNL) Distributed Active Archive Center (DAAC) for Biogeochemical Dynamics

http://www-eosdis.ornl.gov/.

\subsection{Procedures for Obtaining Data}

Users may obtain data directly through the ORNL DAAC online search and order system [http://www-eosdis.ornl.gov/] and the anonymous FTP site [ftp://www-eosdis.ornl.gov/data/] or by contacting User Services by electronic mail, telephone, fax, letter, or personal visit using the contact information in Section 15.1.

\subsection{Data Center Status/Plans}

The ORNL DAAC is the primary source for BOREAS field measurement, image, GIS, and hardcopy data products. The BOREAS CD-ROM and data referenced or listed in inventories on the CD-ROM are available from the ORNL DAAC.

\section{Output Products and Availability}

\subsection{Tape Products}

None given.

\subsection{Film Products}

None given.

\subsection{Other Products}

These data are available on the BOREAS CD-ROM series.

\section{References}

\subsection{Platform/Sensor/Instrument/Data Processing Documentation}

LI-COR Radiation Sensors. 1991. Pub. No. 8609-56. LI-COR, Inc., Lincoln, NE.

\subsection{Journal Articles and Study Reports}

Newcomer, J., D. Landis, S. Conrad, S. Curd, K. Huemmrich, D. Knapp, A. Morrell, J. Nickeson, A. Papagno, D. Rinker, R. Strub, T. Twine, F. Hall, and P. Sellers, eds. 2000. Collected Data of The Boreal Ecosystem-Atmosphere Study. NASA. CD-ROM.

Sellers, P. and F. Hall. 1994. Boreal Ecosystem-Atmosphere Study: Experiment Plan. Version 1994-3.0, NASA BOREAS Report (EXPLAN 94).

Sellers, P. and F. Hall. 1996. Boreal Ecosystem-Atmosphere Study: Experiment Plan. Version 1996-2.0, NASA BOREAS Report (EXPLAN 96).

Sellers, P., F. Hall, and K.F. Huemmrich. 1996. Boreal Ecosystem-Atmosphere Study: 1994 Operations. NASA BOREAS Report (OPS DOC 94).

Sellers, P., F. Hall, and K.F. Huemmrich. 1997. Boreal Ecosystem-Atmosphere Study: 1996 Operations. NASA BOREAS Report (OPS DOC 96). 
Sellers, P., F. Hall, H. Margolis, B. Kelly, D. Baldocchi, G. den Hartog, J. Cihlar, M.G. Ryan, B. Goodison, P. Crill, K.J. Ranson, D. Lettenmaier, and D.E. Wickland. 1995. The boreal ecosystem-atmosphere study (BOREAS): an overview and early results from the 1994 field year. Bulletin of the American Meteorological Society. 76(9):1549-1577.

Sellers, P.J., F.G. Hall, R.D. Kelly, A. Black, D. Baldocchi, J. Berry, M. Ryan, K.J. Ranson, P.M. Crill, D.P. Lettenmaier, H. Margolis, J. Cihlar, J. Newcomer, D. Fitzjarrald, P.G. Jarvis, S.T. Gower, D. Halliwell, D. Williams, B. Goodison, D.E. Wickland, and F.E. Guertin. 1997. BOREAS in 1997: Experiment Overview, Scientific Results and Future Directions. Journal of Geophysical Research 102(D24): 28,731-28,770.

\subsection{Archive/DBMS Usage Documentation \\ None.}

\section{Glossary of Terms}

None.

\section{List of Acronyms}

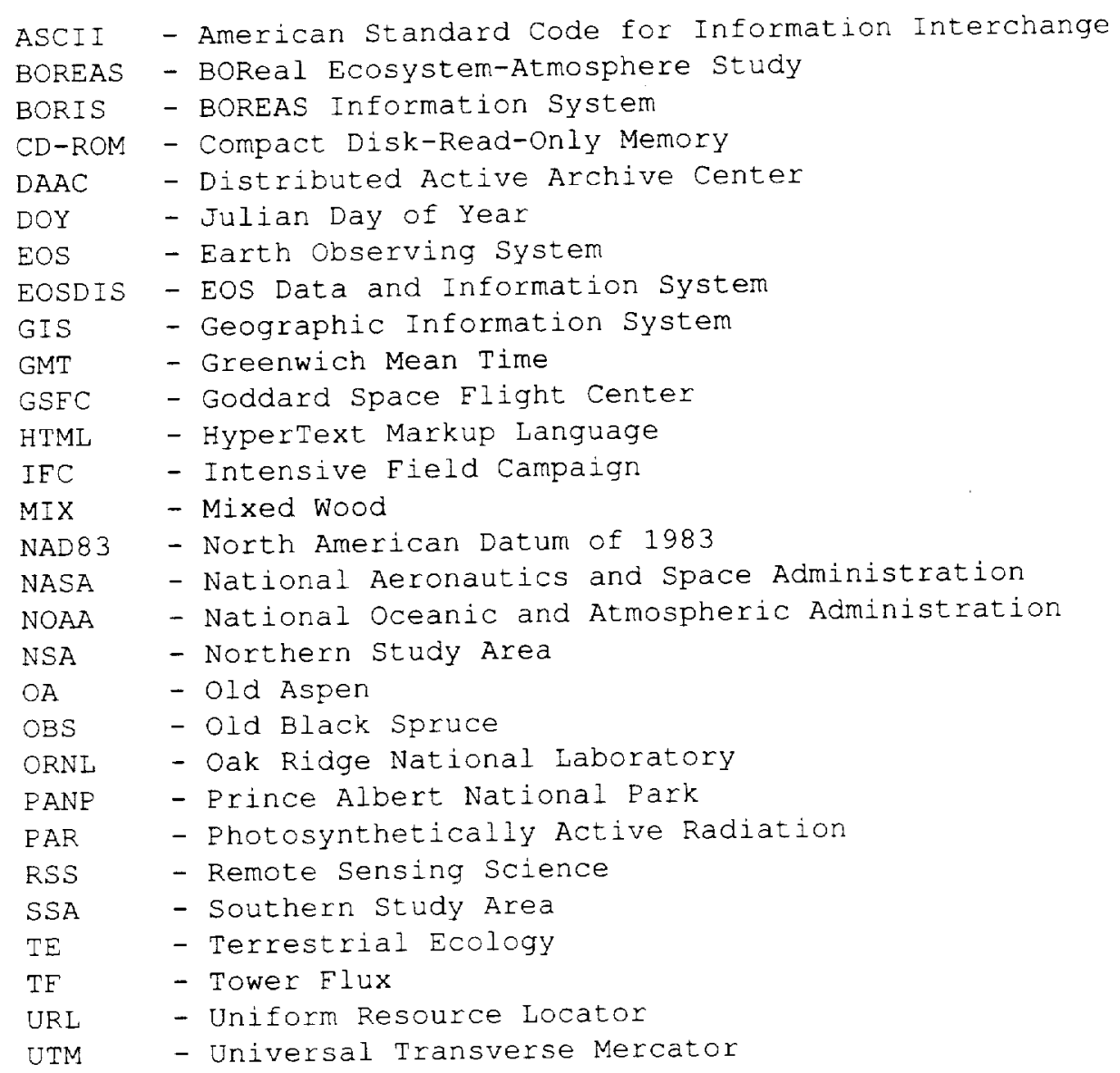




\section{Document Information}

20.1 Document Revision Date

Written: 06-Jan-1999

Last Updated: 17-Sep-1999

20.2 Document Review Date(s)

BORIS Review: 11-Mar-1999

Science Review:

\subsection{Document ID}

\subsection{Citation}

When using these data, please acknowledge E.A. Walter-Shea and M.A. Mesarch, both of UNL, and include citations of relevant papers in Section 17.2.

If using data from the BOREAS CD-ROM series, also reference the data as:

Walter-Shea, E.A., "Radiation and Gas Exchange of Canopy Elements in a Boreal Forest." In Collected Data of The Boreal Ecosystem-Atmosphere Study. Eds. J. Newcomer, D. Landis, S. Conrad, S. Curd, K. Huemmrich, D. Knapp, A. Morrell, J. Nickeson, A. Papagno, D. Rinker, R. Strub, T. Twine, F. Hall, and P. Sellers. CD-ROM. NASA, 2000.

Also, cite the BOREAS CD-ROM set as:

Newcomer, J., D. Landis, S. Conrad, S. Curd, K. Huemmrich, D. Knapp, A. Morrell, J. Nickeson, A. Papagno, D. Rinker, R. Strub, T. Twine, F. Hall, and P. Sellers, eds. Collected Data of The Boreal Ecosystem-Atmosphere Study. NASA. CD-ROM. NASA, 2000.

\subsection{Document Curator}

\subsection{Document URL}


Public reporting burden for this collection of information is estimated to average 9 hour per response, including the time for reviewing instructions. searching existing data sources, athering and maintaining the data needed and completing and reviewing the collection of information. Send comments regarding this burden estimate or any other aspect of this galle Davis Highway. Suite 1204, Artington. VA 22202-4302, and to the Office of Management and Budget. Paperwork Reduction Project (0704-0188), Washington, DC 20503.

\begin{tabular}{l|l|l} 
1. AGENCY USE ONLY (Leave blank) & 2. REPORT DATE & 3. REPORT TYPE AND DATES COVERED
\end{tabular}

\begin{tabular}{r|r|r} 
October 2000 & Technical Memorandum \\
\hline
\end{tabular}

4. TITLE AND SUBTITLE

Technical Report Series on the Boreal Ecosystem-Atmosphere Study (BOREAS)

BOREAS TE-12 Incoming PAR Through the Forest Canopy Data

6. AUTHOR(S)

Elizabeth A. Walter-Shea and Mark A. Mesarch

Forrest G. Hall and Andrea Papagno, Editors

7. PERFORMING ORGANIZATION NAME(S) AND ADDRESS (ES)

Goddard Space Flight Center

Greenbelt, Maryland 20771

9. SPONSORING / MONITORING AGENCY NAME(S) AND ADDRESS (ES)

National Aeronautics and Space Administration

Washington, DC 20546-(0)01
5. FUNDING NUMBERS

923

RTOP: $923-462-33-01$

\section{SUPPLEMENTARY NOTES}

E.A. Walter-Shea and M.A. Mesarch: University of Nebraska-Lincoln;

A. Papagno: Raytheon ITSS, NASA Goddard Space Flight Center, Greenbelt, Maryland

12a. DISTRIBUTION / AVALLABILITY STATEMENT

12b. DISTRIBUTION CODE

Unclassified-Unlimited

Subject Category: 43

Report available from the NASA Center for AeroSpace Information,

7121 Standard Drive, Hanover, MD 21076-1320. (301) 621-0390.

13. ABSTRACT (Maximum 200 words)

The BOREAS TE-12 lcam collected PAR data sets in support of its efforts to characterize and interpret information on sh(s)l geometry, leaf optical properties, leaf water potential, and leaf gas exchange. The data were collected at the SSA-OBS site from 04-Jul-1996 to 25-Jul-1996. The data are stored in tabular ASCll files.

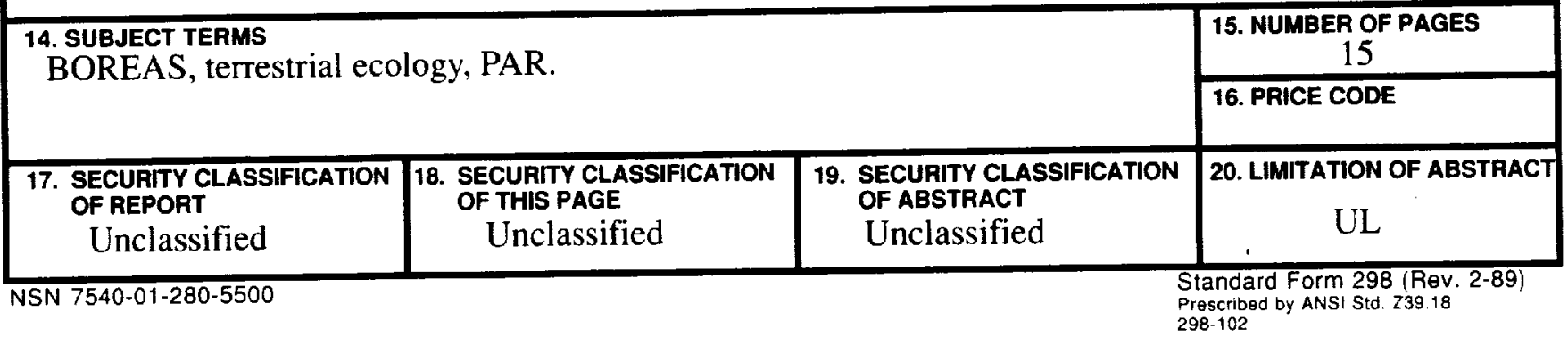

